Д-р техн. наук О.Б. Бабанін (УкрДАЗТ), інж. Ю.М. Грищенко (Укрзалізниця)

\title{
ТЕХНОЛОГІЯ ВІДЦЕНТРОВОЇ РЕГЕНЕРАЦІЇ СИНТЕТИЧНИХ ФІЛЬТРІВ ТЕПЛОВОЗІВ
}

\begin{abstract}
Постановка проблеми у загальному вигляді, іiї зв'язок 3 важливими науковими та практичними завданнями. На цей час пластмаси через їх високу технологічність і мінімальну енергоємність у багатьох випадках витісняють застарілі види матеріалів, які застосовуються в локомотивному господарстві. Ця обставина спонукує переглядати певні можливості їхніх експлуатаційних якостей, а відповідно й застосування нових технологій обслуговування. Такий підхід у повній мірі можна застосувати до синтетичних пропіленово-волокнистих фільтрів, які почали широко застосовуватися в різних системах локомотивів.
\end{abstract}

Аналіз останніх досліджень i публікацій. Останнім часом питанням технології очищення й миття приділяється велика увага. У цьому напрямку проведені значні дослідження з розробленням великої кількості мийного обладнання, нових технологічних процесів і проектів розбірномийних дільниць і цехів [7]. Розроблення синтетичних мийних засобів i нового мийного обладнання в окремих напрямках призвело до корінної перебудови технологічних процесів очищення [2, 39]. Завдяки науковим розробкам сьогодні поновому уявляються способи ультразвукового й віброабразивного очищення $[2,7]$. Разом з тим, у вітчизняній i закордонній літературі не знайшли належного відображення питання, які пов'язані з очищенням деталей із пластмас (особливо відцентровим способом).

Мета статті - дослідити й розробити технологію відцентрової регенерації синтетичних фільтрів тепловозів.

Основна частина (результати експериментального дослідження). Однією 3 найважливіших характеристик будь-якого фільтра, поряд 3 тонкістю фільтрації, пропускною здатністю та його гідравлічним опором, є термін служби між очищенням або замінами. Цей термін визначається інтенсивністю забивання пор частками забруднювача (у даному випадку продуктами забруднення дизельної оливи) i зниженням пропускної здатності фільтра. Останне призводить до збільшення перепаду тиску на фільтрах. Зростання перепаду тиску $є$ непрямим показником його забруднення й при досягненні деякого критичного значення фільтр взагалі перестає працювати. Олива ж у цьому випадку починає циркулювати в обхід фільтруючих елементів за допомогою спеціального пропускного клапана. Тому відрізок часу між початком роботи фільтра й моментом відкриття пропускного клапана називається терміном служби (ресурсом) фільтроелемента [6].

Експериментальними дослідженнями було встановлено [1], що в експлуатації повнопоточні фільтри 3 елементами 
"Нарва-6" у системах змащення вузлів тепловозів працюють 3 непостійною пропускною здатністю. У міру забруднення фільтруючого елемента пропускна здатність фільтра падає, опір у масляній магістралі зростає й при досягненні деякого значення перепаду тиску до та після фільтра відкривається перепускний клапан. При цьому частина неочищеної оливи проходить поза фільтром до системи змащення. У цьому випадку має місце частково поточний режим фільтрації, який негативно відображується на якості змащування пар тертя та дизельної оливи в цілому.

Після розпаду СРСР і утворення незалежної України купувати фільтруючі елементи типу "Нарва-6" в Естонії стало економічно невигідно. У зв'язку з цим на підприємствах України було організоване виробництво цих елементів, які на цей час i встановлюються на тепловози. Однак рівень надійності таких елементів $є$ дуже низьким. Через неякісне виготовлення масово збільшилися розриви фільтруючих шторок в експлуатації, які приводять до повної втрати фільтруючих властивостей повнопоточного фільтра, i, як наслідок, до підвищення бракувальних параметрів оливи.

Виходячи 3 цього для заміни елементів "Нарва-6" ученими кафедри "Експлуатація та ремонт рухомого складу" Української державної академії залізничного транспорту був запропонований принципово новий пористий фільтруючий елемент, виконаний на основі синтетичного матеріалу волокнистого поліпропілену, що виготовляється ТОВ НПП "Рембудсервіс" (м. Харків). Він має ті самі габаритні розміри, що й елемент "Нарва-6", однак відрізняється значною товщиною фільтруючої шторки. Загальний вигляд фільтруючого елемента поліпропіленововолокнистого (ФЕПВ) наведений на рис. 1.

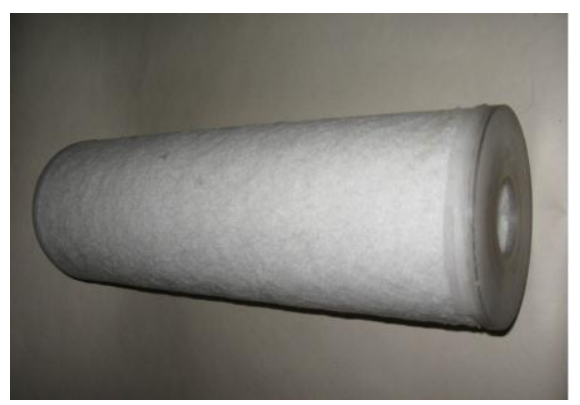

Рис. 1. Синтетичний фільтроелемент ФЕПВ для повнопоточних фільтрів тепловозів

Виконані дослідження та проведені експлуатаційні випробування дозволили отримати такі результати:

- фільтруючі елементи ФЕПВ за такими показниками як пористість та ii зміна в процесі експлуатації, зростання перепаду тисків зі збільшенням пробігу i брудоємності, значно перевищують характеристики існуючих паперових елементів;

- застосування ФЕПВ в 3-5 разів збільшує тривалість їх роботи в порівнянні з існуючими фільтруючими елементами;
- при застосуванні ФЕПВ відпадає необхідність у попередньому просушуванні перед установленням на тепловоз існуючих фільтруючих елементів.

Крім того, за час проведення випробувань оцінювався фізичний стан синтетичних ФЕПВ. При цьому ніяких змін габаритних розмірів, короблення та інших пошкоджень у в відпрацьованих фільтроелементах не було виявлено. Усе це навело на думку про повторне використання відпрацьованих ФЕПВ після 
їх відповідної регенерації. Були проведені додаткові дослідження, які дозволили розробити очисну технологію відцентрової регенерації синтетичних фільтрів.

Основна ідея регенерації (очищення) синтетичних фільтрів ФЕПВ полягає в наступному. Для цього виготовляється додаткове спеціальне обладнання, що встановлюється поруч зі штатною мийною машиною й до якого від цієї машини під тиском підводиться подача миючого розчину. Синтетичний ФЕПВ, який необхідно очистити, вставляється в це обладнання, закривається спеціальним кожухом i за допомогою електродвигуна починає обертатися. При обертанні усередину ФЕПВ під тиском подається миючий розчин. У результаті цього через дію відцентрових сил, які виникають миючий розчин вимиває всі його фільтруючі канали.

Загальна схема обладнання показана на рис. 2.

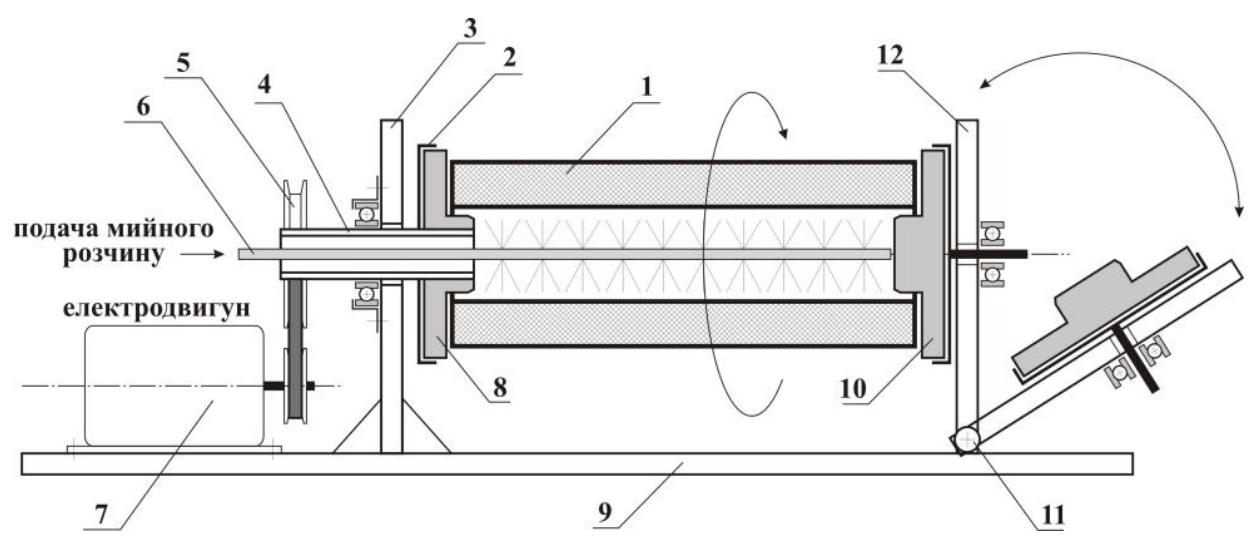

Рис. 2. Схема обладнання для відцентрової регенерації синтетичних фільтрів ФЕПВ:

1 - ФЕПВ; 2 - утримуюча таріль; 3 - передній жорсткий стояк; 4 - порожній вал;

5 - шків пасової передачі; 6 - трубка для підведення миючої рідини; 7 - електродвигун;

8 - упор передній; 9 - рама; 10 - упор задній; 11 - шарнір; 12 - задній гнучкий стояк

Основу конструкції обладнання становить рама 9, виконана з кутка, на якій встановлені передній жорсткий стояк 3 i задній гнучкий стояк 12 , який може відкидатися. У передньому стояку 3 на підшипнику закріплюється порожній вал 4, 3 одного боку якого приварюється утримуюча таріль 2, а 3 іншого боку насаджується маховик 5 для зв'язку пасової передачі 3 електродвигуном 7. 3 іншого боку рами на шарнірі 11 закріплюється гнучкий відкидний стояк 12 , до якого на підшипнику закріплюється аналогічна таріль, що $є$ на передньому стояку. У кожну таріль вставляються спеціальні пружні вставки 8 (для передньої тарілі) і 10 (для задньої тарілі). Задній гнучкий відкиднийся стояк 12 за допомогою шарнірного з'єднання 11 може відкидатися на певний кут, що дозволяє закріплювати в обладнанні синтетичний фільтроелемент 1 , який необхідно очистити. У порожній вал 4 переднього стояка 3 вставляється трубка 6 , яка забезпечує підведення під тиском миючого розчину для очищення синтетичного ФЕПВ.

Вся конструкція обладнання для очищення синтетичних фільтрів ФЕПВ закривається спеціальним кожухом. При цьому електродвигун, для виключення попадання на нього розчину й бруду, встановлюється зовні цього кожуха. Обладнання 3 кожухом встановлюється поруч зі штатною мийною машиною. 


\begin{abstract}
Проведені випробування 3 відцентрової регенерації синтетичних фільтрів дали позитивний результат i визначили надалі можливість повторного використання ФЕПВ в системах тепловозів. На цей час в локомотивних депо Основа й Харків-сортувальний проводяться пусконалагоджувальні роботи 3 коректуванням існуючих технологічних процесів.
\end{abstract}

\section{Висновки і рекомендації}

1. У статті розглянуті особливості роботи синтетичних фільтрів ФЕПВ та можливість їх подальшого використання після відповідного очищення від забруднень дизельної оливи.

2. Запропоновано рішення щодо відцентрової регенерації синтетичних фільтрів ФЕПВ 3 розробленням відповідного технологічного обладнання, яке дозволяє працювати разом із штатною мийною машиною, яка $\epsilon$ в локомотивному депо.

\section{Сиисок літератури}

1. Бабанин, А.Б. Очистка масел тепловозов синтетическими фильтрами [Текст] / А.Б. Бабанин, Ю.М. Грищенко, А.П. Мазняк // Локомотив-информ. - 2008. - № 9. - С. 29-31.

2. Белянин, П.Н. Промышленная чистота машин [Текст] / П.Н. Белянин, В.М. Данилов. - М.: Машиностроение, 1982. - 224 с.

3. Беренсон, С.П. Химическая технология очистки деталей двигателей внутреннего сгорания [Текст] / С.П. Беренсон. - М.: Транспорт, 1988. - 268 с.

4. Козлов, Ю.С. Очистка автомобилей при ремонте [Текст] / Ю.С. Козлов. - М.: Транспорт, 1975. - 216 с.

5. Крутоус, Е.Б. Техника мойки изделий в машиностроении [Текст] / Е.Б. Крутоус, М.И. Некрич. - М.: Машиностроение, 1989. - 239 с.

6. Морозов, Г.А. Очистка масла в дизелях [Текст] / Г.А. Морозов, Арциомов. - Л.: Машиностроение, 1971. - 352 с.

7. Рахматулин, М.Д. Технология ремонта тепловозов [Текст] / М.Д. Рахматулин. - М.: Транспорт, 1983. - 319 с.

8. Савченко, В.И. Очистка и мойка машин [Текст] / В.И. Савченко. - М.: Россельхозиздат, 1974. - 124 с.

9. Тельнов, Н.Ф. Технология очистки сельскохозяйственной техники [Текст] / Н.Ф. Тельнов. - М.: Колос, 1983. - 256 с.

10. ТУ У 29.2-31061660-002:2011. Елементи фільтрувальні синтетичні поліпропіленововолокнисті. Технічні умови [Текст]. - К.: Держстандарт України, 2011.

11. Харламов, П.Г. Воздушные, масляные и топливные фильтры тепловозов [Текст] / П.Г. Харламов, В.Д. Кузьмич, Э.А. Пахомов. - М.: Транспорт, 1965. - 165 с.

Ключові слова: забруднення, олива, очистка, повнопоточний, регенерація, розчин, синтетичний, стояк, тепловоз, фільтроелемент.

\section{Анотаціі}

У статті розглянуті особливості роботи синтетичних фільтрів та можливість їх подальшого використання в системах тепловозів після відповідного очищення від забруднень дизельної оливи. Запропоновано рішення щодо відцентрової регенерації синтетичних фільтрів з розробленням відповідного технологічного обладнання, яке дозволяє працювати разом із штатною мийною машиною, яка є в локомотивному депо. 
В статье рассмотрены особенности работы синтетических фильтров и возможность их дальнейшего использования в системах тепловозов после соответствующей очистки от загрязнений дизельного масла. Предложено решение по центробежной регенерации синтетических фильтров с разработкой соответствующего технологического оборудования, которое позволяет работать совместно со штатной моечной машиной, которая имеется в локомотивном депо.

In article features of work of synthetic filters and an opportunity of their further use in systems of diesel locomotives after corresponding clearing of pollution of diesel oil are considered. The decision on centrifugal regeneration of synthetic filters with development of the corresponding process equipment which allows to work in common with regular washing machine which is available in locomotive depot is offered. 